\title{
Role of Regulatory Immune Cells and Molecules in Autoimmune Bullous Dermatoses
}

\author{
Tianyu Cao ${ }^{1 \dagger}$, Shuai Shao ${ }^{2 \dagger}$, Hui Fang ${ }^{2 \dagger}$, Bing $\mathrm{Li}^{2}$ and Gang Wang ${ }^{2 *}$ \\ ${ }^{1}$ Department of Dermatology, Tangdu Hospital, Fourth Military Medical University, Xi'an, China, ${ }^{2}$ Department of Dermatology, \\ Xijing Hospital, Fourth Military Medical University, Xi'an, China
}

Autoimmune bullous dermatoses (AIBD) include a series of typical organ-specific autoimmune diseases characterized by extensive mucocutaneous blisters. It is generally accepted to be caused by pathological autoantibodies that directly target specific adhesion components of the skin or the adjacent mucous membranes. Both innate and adaptive immune systems are critically involved in the misguided immune response against self-antigens. Recent studies have indicated that the dysfunction of regulatory $T$ cells, regulatory B cells, and complement regulatory proteins that play essential roles in

OPEN ACCESS

Edited by:

Michele Marie Kosiewicz, University of Louisville, United States

Reviewed by:

Maria I. Bokarewa, University of Gothenburg, Sweden

Åsa Andersson,

Halmstad University, Sweden

*Correspondence:

Gang Wang

xjwgang@fmmu.edu.cn

†These authors have contributed equally to this work

Specialty section:

This article was submitted to Autoimmune and Autoinflammatory

Disorders,

a section of the journal

Frontiers in Immunology

Received: 31 March 2019

Accepted: 10 July 2019

Published: 02 August 2019

Citation:

Cao T, Shao S, Fang H, Li B and Wang G (2019) Role of Regulatory Immune Cells and Molecules in Autoimmune Bullous Dermatoses.

Front. Immunol. 10:1746. doi: 10.3389/fimmu.2019.01746 maintaining a healthy immune environment is also closely related to immune disorders in AIBD. It is important to summarize these studies, elucidate the changes in these regulatory immune cells and molecules for the pathogenesis of AIBD, and reveal the mechanisms by which they lose their ability to regulate immune disorders. In this review, we highlight the role of regulatory immune cells and molecules in the pathogenesis of pemphigus vulgaris and bullous pemphigoid, the two most representative forms of AIBD, and indicate issues that should be addressed in future investigations.

Keywords: regulatory $\mathrm{T}$ cells, regulatory B cells, complement regulating proteins, pemphigus vulgaris, bullous pemphigoid

\section{INTRODUCTION}

The immune system is guided by a series of regulatory mechanisms, the main components of which are a large number of immunoreactive and suppressor cells, that modulate the host response (1). Various immune cells and molecules that have been found to possess a regulatory capacity include regulatory $\mathrm{T}$ (Treg) cells, regulatory B (Breg) cells, macrophages, myeloid-derived suppressor cells (MDSCs), dendritic cells (DCs), mesenchymal stromal cells (MSCs), and complement regulatory proteins (CRPs) (2). Alteration or disruption of these immune regulatory mechanisms may lead to the survival and activation of autoreactive lymphocytes upon encountering appropriate selfantigens, which may cause corresponding tissue and organ damage (2). For instance, regulatory immune mechanisms have been implicated in the development of many autoimmune disorders, such as systemic lupus erythematosus (SLE), rheumatoid arthritis, and multiple sclerosis (3-5).

Autoimmune bullous dermatoses (AIBD) include a series of diseases that cause blistering of the skin and mucous membranes through autoantibody attacks on keratinocyte junction structures or on components of the dermal-epidermal junction (6). Based on the location of its formation, AIBD can be divided into two subgroups: pemphigus and pemphigoid diseases (7). Pemphigus diseases are characterized by the production of $\operatorname{IgG}$ autoantibodies against keratinocyte adhesion molecules, resulting in intraepidermal blistering, flaccid vesicles, and erosions of the skin 
and/or mucous membranes. Diseases in this group include pemphigus vulgaris (PV), pemphigus foliaceus, paraneoplastic pemphigus, and IgA pemphigus (6). In contrast, pemphigoid diseases are characterized by autoantibodies that directly attack structural proteins within the dermal-epidermal junction, leading to urticarial lesions, and tense blisters on the skin (8). This group includes bullous pemphigoid (BP), linear IgA bullous dermatosis, dermatitis herpetiformis, mucous membrane pemphigoids, herpes gestationis, and epidermolysis bullosa acquisita (7).

Recent studies have shown several regulatory immune cells and molecules to be involved in the progression of AIBD. In this review, we aim to elucidate the different mechanisms and roles of regulatory immune cells and molecules in AIBD by summarizing and discussing the findings of various clinical and experimental studies, and outline some of the challenges that lie ahead.

\section{CLINICAL PRESENTATION AND PATHOPHYSIOLOGY OF AIBD}

\section{Clinical and Immunohistological Features}

The pemphigus group of AIBD contains several rare organ specific autoimmune diseases that affect the skin and mucous membranes (9). PV, as the most common representative disease of the pemphigus group (10), is characterized by extremely painful erosions of the mucous membranes, and flaccid blisters localized mainly in the flexural areas, face, scalp, and extremities (Figures 1A,B). Typical lesional biopsy specimens of PV show acantholysis, which can progress to the formation of non-inflammatory intraepithelial blisters; however, a few eosinophils or neutrophils can be occasionally seen in the upper dermis and epidermis as well (Figure 1C). Meanwhile, direct immunofluorescence (DIF) of perilesional biopsy specimens from patients with PV shows IgG antibodies, and infrequently complement C3 protein, deposits on the surface of keratinocytes (Figure 1D). Whereas, DIF of normal skin shows no specific fluorescence (Supplementary Figure 1). Indirect immunofluorescence (IIF) using monkey or human normal skin as substrates enables a semiquantitative detection of circulating autoantibodies in serum. And IIF typically shows serum IgG autoantibodies from patients with PV bound to the surface of epithelium (Figure 1E).

$\mathrm{BP}$ is the most frequently occurring representative of the pemphigoid group, and is clinically characterized by tense, serous, or hemorrhagic bullae on erythematous or apparently

Abbreviations: AIBD, autoimmune bullous dermatoses; ARG1, arginase-1; BP, bullous pemphigoid; Breg cells, regulatory B cells; B10eff cells, functional IL-10secreting effector B cells; B10pro cells, IL-10-secreting progenitor B cells; CRPs, complement regulatory proteins; CTLA-4, cytotoxic T-lymphocyte associated protein 4; DCs, dendritic cells; DIF, direct immunofluorescence; Dsg, desmoglein; EAE, experimental autoimmune encephalomyelitis; H\&E, haematoxylin and eosin; IDO, indoleamine 2,3-dioxygenase; IIF, indirect immunofluorescence; IL, interleukin; IVIG, intravenous immunoglobulin; mAb, monoclonal antibody; BMZ, basement membrane zone; MCs, mast cells; MDSCs, myeloid-derived suppressor cells; MSCs, mesenchymal stromal cells; NC16A, non-collagenous 16A; NK cells, natural killer cells; nTreg cells, natural Treg cells; PV, pemphigus vulgaris; SLE, systemic lupus erythematosus; TGF- $\beta$, transforming growth factor- $\beta$; TNF- $\alpha$, tumor necrosis factor- $\alpha$; Treg cells, regulatory T cells; Tr1 cells, regulatory type 1 cells. normal skin (Figures 1F,G). The lesional biopsy specimens of BP typically reveal sub-epidermal blister formation with eosinophil and/or neutrophil-rich inflammatory infiltration in the superficial dermis (Figure $\mathbf{1 H}$ ). In addition, DIF of BP lesions shows the deposits of IgG and/or C3 along the basement membrane zone (BMZ) (Figure 1I), and $\operatorname{IgA}$ and $\operatorname{IgE}$ were occasionally seen in a similar pattern (11). IIF also shows circulating IgG antibodies form patients with BP bound to the dermoepidermal junction (Figure 1J).

\section{Genetic Factors}

Although the genetic background of AIBD has not been precisely determined, a genetic predisposition in the etiology is evident. The human HLA class I and II molecules play a critical role in the recognition of antigenic peptides by $\mathrm{T}$ cells. Several HLA alleles, including HLA-DRB1*0402 (in Jewish people) and HLA-DQB1*0503 (in non-Jewish populations), have been found to be strongly associated with PV (12). Meanwhile, in BP, HLA-DQB1*03:01 is considered the most common HLA class II allele, associated with patients in multiple populations (13-15). Other HLA alleles, such as HLADRB1*04, $\mathrm{DRB}^{*} 1101$, and DQB1*0302, were more frequent in Japanese patients with BP (16), suggesting different HLA class II haplotypes to genetically influence susceptibility to BP across different populations.

\section{Autoantibody Mediated Blister Formation}

The binding of autoantibodies to antigens is universally known as the main cause of blister formation in AIBD. The autoantibodies in PV are against the members of cadherin family, desmoglein (Dsg) 1, and Dsg3, which maintain intercellular adhesion in stratified squamous epithelia $(17,18)$. The main mechanism of blister formation in $\mathrm{PV}$ is steric hindrance, since atomic force microscopy experiments had shown that PV IgG can directly inhibit Dsg3-mediated transinteraction (19). Besides this, several cell signaling pathways and factors are also involved in the blister formation in PV, including p38 mitogen-activated protein kinase (MAPK) (20), c-Myc (21), epidermal growth factor receptor (22), caspases (23), and mitochondria (24).

The autoantibodies in BP target two components of the hemidesmosome adhesion complex, BP180 (collagen XVII) and BP230 (dystonin-e), and the non-collagenous 16A (NC16A) domain of BP180 contains the major epitopes recognized by autoreactive $\mathrm{T}$ and $\mathrm{B}$ cells (25). In contrast to that in PV, the formation of sub-epidermal blisters in BP depends mainly on the autoantibody-induced inflammation, including activation of complement, degranulation of mast cells (MCs), and activation of neutrophils, since the knockdown of C4 (component of classical complement activation pathway), C5aR (expression on MCs), MC protease-4 (homolog of the human MC chymase), and Fc $\gamma$ RIII (the main receptor on neutrophils) were, respectively, resistant to anti-BP180 antibody induced blistering in mice (2630 ). Besides, neutrophil elastase, matrix metalloproteinase-9, and other proteolytic enzymes released by neutrophils could directly split the epidermis from the dermis (31). 

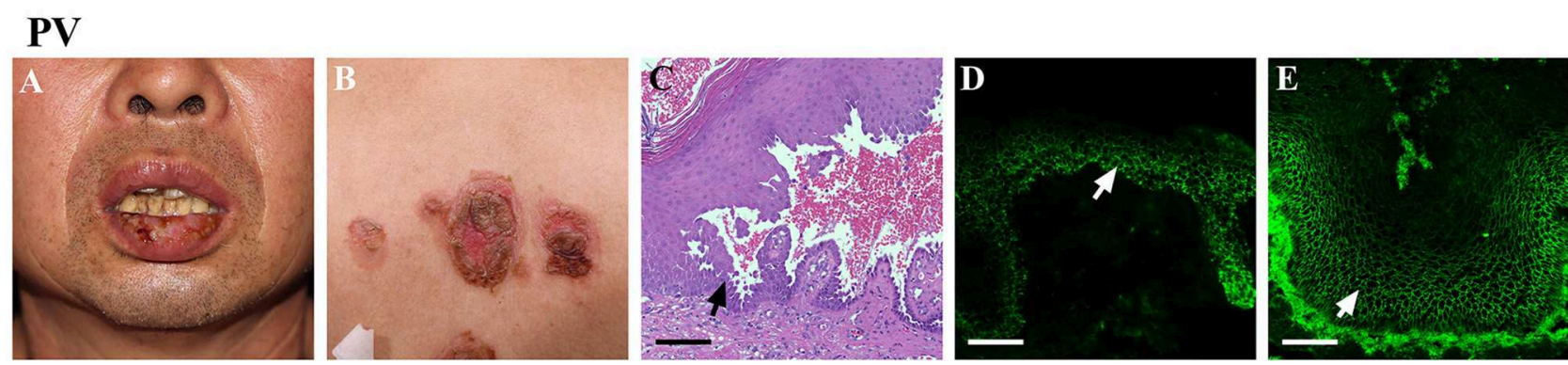

\section{BP}
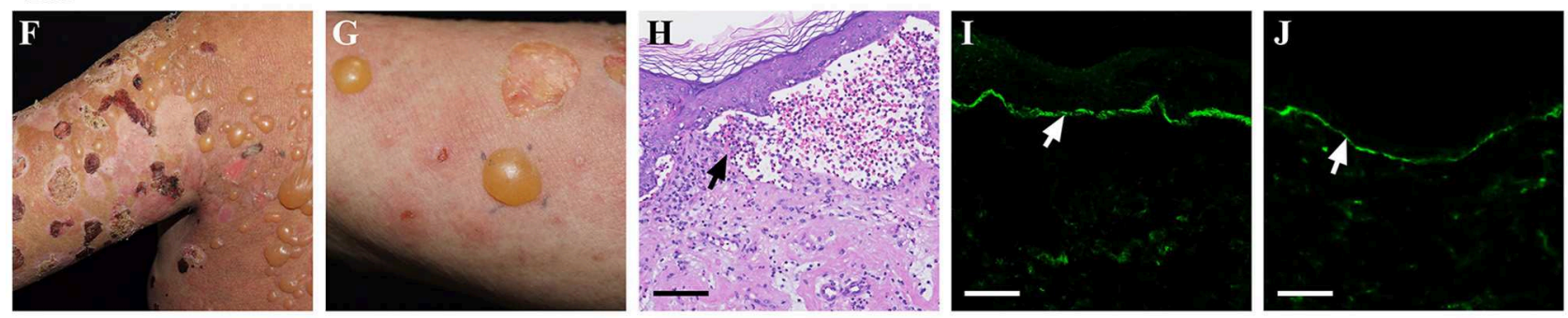

FIGURE 1 | Clinical and immunohistological features of AIBD. AIBD contains two groups: pemphigus group and pemphigoid group. The representative members of these two groups are PV and BP. PV can present with erosions on the mucous membranes (A), and flaccid vesicles or erosion on the skin (B). Haematoxylin and eosin (HandE) staining of PV lesions demonstrates an intraepithelial blister with acantholysis (C). DIF of PV lesions shows IgG antibodies deposit on the surface of keratinocytes (D). IIF using monkey esophagus shows serum IgG autoantibodies from patients with PV bind to the surface of epitheliums (E). Whereas, BP presents with large, tense bullae, and erythematous patches on the skin (F,G). H \& E staining of BP lesions reveals an subepidermal blister with eosinophil-rich inflammatory infiltration in the superficial dermis (H). DIF of BP lesions shows IgG antibodies deposit along the dermoepidermal junction (I). IIF using normal skin shows the presence of serum IgG antibodies form BP patients bound to the dermoepidermal junction (J). Bar = $100 \mu \mathrm{m}$.

\section{Animal Models}

Although no single animal model could completely simulate the entire process of $\mathrm{PV}$ and $\mathrm{BP}$, several models have been developed for different areas of research. For PV, passive transfer with circulating IgG antibodies, from patients with PV, could induce a PV-like phenotype in neonatal mice (32), which can be used to study the function of autoantibodies. In addition, adoptive transfer of peripheral lymphocytes from $\mathrm{Dsg} 3^{-/-}$ mice to Rag- $2^{-/}$immunodeficient mice could also develop a PV-like phenotype (33). This model may be used to isolate anti-Dsg3 monoclonal antibodies, investigate the roles of $\mathrm{T}$ and $\mathrm{B}$ lymphocytes in perpetuating autoantibody production for autoimmune response, and evaluate immunosuppressive therapeutic strategies $(34,35)$.

On the other hand, passive transfer with IgG autoantibodies from patients with BP could not induce a BP-like disease in animals, since BP autoantibodies reacting with NC16A domain failed to cross-react with mouse BP180. In 1993, Liu et al. had reported an experimental $\mathrm{BP}$ model by transferring rabbit antimouse BP180 NC14A into neonatal mice, which developed the same clinical, histological, and immunopathological features of BP (36). This model has been widely used to investigate the roles of autoantibodies, complement, MCs, neutrophils, and Fc $\gamma$ Rs in BP $(28,30,37)$. Additionally, in humanized mouse whose murine $\mathrm{BP} 180 \mathrm{NC} 14 \mathrm{~A}$ is replaced with the homologous human BP180NC16A epitope cluster region, injection of antiBP180NC16A autoantibodies result in the development of BPlike subepidermal blisters (25).

\section{TREG CELLS IN AIBD \\ CD4 $^{+}$CD25 $^{\text {Bright }}$ FoxP3 $^{+}$Natural Treg (nTreg) Cells}

The pathogenetic progress of AIBD includes a series of immune events, including activation of autoreactive $\mathrm{T}$ cells, T-B cell interaction, autoantibody production, and blister formation (38). Recent studies have indicated the involvement of regulatory immune cells and molecules as well in AIBD. Although a wealth of regulatory immune cells have been identified, $\mathrm{CD} 4^{+}$ $\mathrm{CD} 25^{\text {bright }} \mathrm{FoxP}^{+}{ }^{+}$natural Treg (nTreg) cells remain the most extensively studied cell-type (39). In 1995, Sakaguchi et al. firstly reported and defined a subset of $\mathrm{CD}^{+}$cells showing stable expression of the lineage-specific transcription factor FoxP3 and high concentrations of the interleukin 2 (IL2) receptor $\alpha$-chain (CD25) (40). $\mathrm{CD}^{+} \mathrm{CD}^{\text {bright }} \mathrm{FoxP}^{+}$Treg cells account for $10 \%$ of peripheral $\mathrm{CD} 4^{+} \mathrm{T}$ cells and demonstrate the suppressing function, both in cell contact-dependent and -independent manner (41). CD4 ${ }^{+} \mathrm{CD} 25^{\text {bright }} \mathrm{FoxP}^{+}$Treg cells expressed cytotoxic T-lymphocyte associated protein 4 (CTLA-4), CD25, CD39, and CD73 ectoenzymes, which directly suppressed the production of $\mathrm{CD} 8^{+} \mathrm{T}$ cells, DCs, myeloid cells, and possibly natural killer (NK) cells (42-44). Moreover, $\mathrm{CD} 4^{+} \mathrm{CD} 25^{\text {bright }} \mathrm{FoxP}^{+}$Treg cells can also produce a variety of immunomodulatory cytokines, such as IL-10, granzymes, and transforming growth factor- $\beta$ (TGF- $\beta$ ), which suppress the proinflammatory responses of effector T cells, NK cells, B cells, DCs, and macrophages (45). 


\section{nTreg Cells in Pemphigus Vulgaris}

The concentration and function of $\mathrm{CD}^{+}{ }^{+} \mathrm{CD} 25^{\text {bright }} \mathrm{FoxP}^{+}$ Treg cells in patients with PV are abnormal. Sugiyama et al. (46) found that $\mathrm{CD} 4^{+}$Treg cells were remarkably reduced in the blood of patients with PV (46). In addition, CD4 ${ }^{+}$CD25 bright Treg cells in such patients showed significantly higher CD45RO and lower CD45RA expression levels than in normal controls. Moreover, the expression of FoxP3 and CTLA-4 in CD ${ }^{+}$CD25 bright Treg cells was significantly down-regulated in patients with $\mathrm{PV}$ compared to that in healthy people, along with dysregulation of CCR4 and CCL22 expression $(46,47)$, thus suggesting the possibility of defective trafficking of Treg cells in skin lesions of patients with PV. Furthermore, the number of $\mathrm{CD}^{+}{ }^{+}$Treg cells was negatively correlated with that of Th17 cells, which is significantly increased in patients with PV (48). This imbalance might be an important factor in the progression of PV. Importantly, recent studies have indicated that increasing the number of $\mathrm{CD} 4{ }^{+} \mathrm{CD} 25^{\text {bright }}$ FoxP $3^{+}$Treg cells, by adoptive transfer or use of the super-agonistic anti-CD28 antibody D665, could suppress antibody production in mouse models of PV, whereas depleting them enhanced the autoantibody production in the same model $(49,50)$. These results suggested that $\mathrm{CD}^{+}{ }^{+} \mathrm{CD} 25^{\text {bright }}$ FoxP3 $^{+}$Treg cell dysfunction promotes the progression of $\mathrm{PV}$.

However, there have been several studies that showed inconsistent results for the change of nTreg cells after treatment. Bhattacharjee et al. found no obvious changes in $\mathrm{CD} 4{ }^{+} \mathrm{CD} 25^{+}$ FoxP $^{+} \mathrm{T}$ cell counts in patients with PV after monotherapy with rituximab, an anti-CD20 monoclonal antibody that could induce B cell depletion and is commonly used in autoimmune diseases $(51,52)$. El-Zawahry et al. however showed that the circulating $\mathrm{CD}^{+} \mathrm{CD} 25^{+} \mathrm{T}$ cells in patients with $\mathrm{PV}$ were reduced after treatment with rituximab (53). In several other autoimmune diseases, such as lupus nephritis, idiopathic thrombocytopenic purpura, myasthenia gravis, and rheumatoid arthritis, treatment with rituximab significantly increased the growth of $\mathrm{CD}^{+}{ }^{+} \mathrm{CD} 25^{\text {bright }} \mathrm{FoxP}^{+}$Treg cells (54-57). These discrepancies in the results may be due to the limited number of samples, or differences in the pathogenesis of each disease. Therefore, whether nTreg cells function as a therapy against PV is still debatable.

In brief, defects in the growth and function of nTreg cells, not only reduce the excessive response limit of Th cells, but also promote the production of autoantibodies, thus contributing to the development of PV (Figure 2). However, the molecular mechanism controlling the suppression of nTreg cells, as well as their therapeutic potential, warrants further investigations.

\section{nTreg Cells in Bullous Pemphigoid}

In patients with $\mathrm{BP}$, the number of $\mathrm{CD} 4^{+} \mathrm{CD} 25^{\text {bright }} \mathrm{FoxP}^{+}$ Treg cells was found to be significantly reduced, both in the blood and skin $(58,59)$. In addition, the function of $\mathrm{CD}^{+}$ CD25 ${ }^{\text {bright }}$ FoxP3 $^{+}$Treg cells in BP has also been found to be abnormal. For instance, a study had shown that scurfy mice, which carry FoxP3 gene mutations, lacked functional Treg cells, displayed severe erosive skin lesions similar to that in BP, and produced autoantibodies targeting murine BP230 and BP180. Moreover, the transfer of CD4+ T cells from scurfy mice to immunodeficient mice induced the expression of autoantibodies targeting BP230 and BP180, and this phenomenon was ameliorated in STAT6 gene knockout mice (60). An additional study had discovered that the formation of sub-epidermal blisters in scurfy mice is caused by the monoclonal antibody (mAb) 20B12, which could cross-react with human BP230 (61). These studies together suggest that the absence of FoxP3 ${ }^{+}$ Treg cells leads to the BP phenotype in mice by inducing the expression of pathogenic autoantibodies targeting BP antigens (Figure 2). Further research is required to clarify the immunological mechanisms controlling the inhibition of autoantibody production by $\mathrm{CD}^{+}{ }^{+}$Treg cells and to understand why this function is lost in BP.

Another study had shown that CD25 high Treg cells were in similar proportions to that of $\mathrm{CD}^{+} \mathrm{T}$ cells in $\mathrm{BP}$ and healthy blood, and that the ability of $\mathrm{CD} 4^{+} \mathrm{CD} 25^{\text {high }}$ Treg cells to suppress $\mathrm{T}$ cell proliferation and interferon- $\gamma$ (IFN- $\gamma$ ) secretion in patients with BP was similar to that in normal individuals (62). Although the results seemed to be contradictory, CD4 and CD25, by themselves, are not sufficient to identify Treg cells. CD4 ${ }^{+}$CD25 $5^{\text {bright }}$ cells may represent not only Treg cells, but also FoxP3- activated $\mathrm{T}$ cells. The inconsistent results may have been caused by the different phenotypes of Treg cells.

\section{Induced Treg (iTreg) Cells}

Besides thymus-derived FoxP3 ${ }^{+}$nTreg cells, there are several other types of Treg cells that can be induced from peripheral naive $\mathrm{T}$ lymphocytes in the periphery, including FoxP $3^{+}$iTreg cells (63), IL-10-producing T regulatory type 1 ( $\operatorname{Tr} 1)$ cells (64), TGF- $\beta$-secreting Th3 cells (65), and B-cell-induced Foxp3 ${ }^{-}$ regulatory T cells (Treg-of-B cells) (66). Among them, Tr1 cells are the most extensively studied type. Tr1 cells were first reported in 1997 and could produce high levels of IL-10 and TGF- $\beta$, which played a key role in suppressing antigen-specific $\mathrm{T}$ cell responses (67).

Veldman et al. had shown that Dsg3-responsive Tr1 cells, isolated from healthy carriers of two PV-associated HLA class II alleles (DRB1*0402 and DQB1*0503), were present in significantly higher proportions than in patients with $\mathrm{PV}$. This population of cells secreted IL-10, TGF- $\beta$, and IL-5 in response to Dsg-3, and inhibited the proliferation of Dsg3-reactive Th cells (68). The Dsg3-responsive Tr1 cells could be divided into two subpopulations based on their cell size and granularity. The smaller subset expressed FoxP3 and secreted IL-10 and TGF- $\beta$ in response to Dsg3 stimulation. The larger subset, on the other hand, did not express FoxP3, exhibited a Th celllike phenotype, and secreted IL-2 (69) (Figure 2). Inhibition of FoxP3 mRNA in Tr1, using antisense oligonucleotides resulted in the cells showing features similar to those of Th2 cells, such as the secretion of IL-2 and loss of anergy in response to Dsg3 antigen stimulation (70). After treatment with rituximab, the mean count of $\operatorname{Tr} 1$ cells increased in 2 weeks, and gradually declined over the remaining period (51). In summary, alterations in the growth and function of Dsg3- responsive $\operatorname{Tr} 1$ cells in 


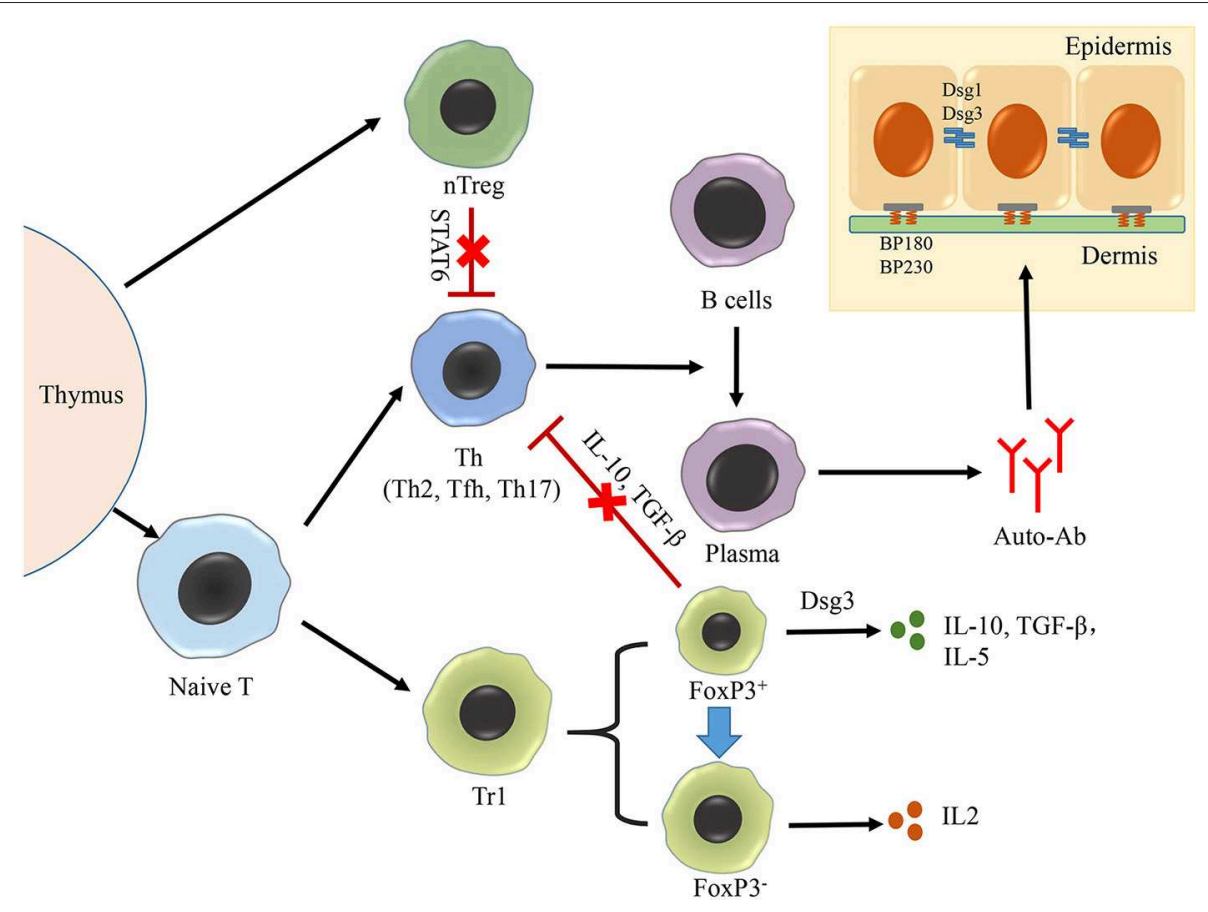

FIGURE 2 | Role of treg cells in AIBD. The production of autoantibodies by plasma cells is the crucial process in the pathogenesis of both PV and BP, in which Th-B cell interaction plays an important role. Treg cells can be divided into two groups: nTreg cells and iTreg cells. nTreg cells number is decreased in PV, which have a negative correlation with Th17 cells. nTreg cells could suppress the functions of Th2 and Tfh cells on activing B cells in an STAT6-dependent manner, but they lost this function in BP. Additionally, $\operatorname{Tr} 1$ cells, the most intensively studied cell type of iTreg cells, could be divided into two subpopulations based on the cell size and granularity in PV. The smaller subset achieves the suppressing function by secreting IL-10, TGF- $\beta$ in response to Dsg3. The larger subset loses the ability in response to Dsg3, exhibits a Th cell-like phenotype, and secretes IL-2.

PV, as well as their inhibitory effect on Th cells, indicate their relevance in PV pathogenesis. Future studies should focus on the underlying mechanisms controlling phenotypic changes in $\operatorname{Tr} 1$ cells during PV pathogenesis, and the development of related PV treatment strategies.

Not enough evidence in AIBD accounts for the changes in other iTreg cell subsets. One study had shown that the proportion of TGF- $\beta$-secreting Th3 cells did not change in PV cases compared to that in normal individuals, although there was an increase in the mean value at 14 weeks after treatment with rituximab (51). Since the phenotypic identification on Treg cells has long been inconsistent, reliability of some studies of Treg cells remains debatable. Future studies should be based on the improved classification and identification of Treg cell subsets to further determine the changes in number and function of these cell subsets in AIBD.

\section{CD8 $^{+}$Treg Cells}

While $\mathrm{CD} 4^{+}$Treg cells have attracted much attention for their important role in the regulation of immune homeostasis, recent findings have also identified a subset of $\mathrm{CD}^{+} \mathrm{T}$ cells with immunoregulatory functions, known as $\mathrm{CD} 8^{+}$Treg cells (7173). Till date, three subsets of $\mathrm{CD}^{+}$Treg cells have been identified: $\mathrm{CD}^{+}{ }^{+} \mathrm{CD} 25^{+} \mathrm{T}$ cells, $\mathrm{CD} 8^{+} \mathrm{CD} 122^{+} \mathrm{T}$ cells, and $\mathrm{CD}^{+}{ }^{+} \mathrm{CXCR}^{+} \mathrm{T}$ cells. $\mathrm{CD} 8^{+} \mathrm{CD} 25^{+}$Treg cells express surface CTLA-4 and GITR, as well as intracellular FoxP3, similar to that observed in $\mathrm{CD} 4^{+}$Treg cells (74). Meanwhile, $\mathrm{CD}{ }^{+} \mathrm{CD} 25^{+}$ Treg cells could directly contact $\mathrm{CD} 4^{+} \mathrm{CD} 25^{-} \mathrm{T}$ cells and down-regulate the expression of IL-2R $\alpha$, thus suppressing the growth of target cells $(74,75)$. In addition, human $\mathrm{CD}^{+}$ $\mathrm{CXCR}^{+} \mathrm{T}$ cells were found to suppress the expression of IFN$\gamma$ in immune cells by secreting IL-10, similar to the observed mechanism in murine $\mathrm{CD} 8^{+} \mathrm{CD} 122^{+}$Treg cells $(76-78) . \mathrm{CD}^{+}$ FoxP3 ${ }^{+}$Treg cells were also found to play an important role in the up-regulation of FoxP3 and proliferation of $\mathrm{CD}^{+}$ CD25 ${ }^{+}$Treg cells (79). Although an association between $\mathrm{CD}^{+}$ Treg cells and several autoimmune diseases, such as SLE and experimental autoimmune encephalomyelitis (EAE) has been identified $(80,81)$, evidence linking $\mathrm{CD}^{+}$Treg cells to AIBD is still lacking.

\section{BREG CELLS IN AIBD}

Breg cells were first identified as a subset of IL-10-producing B cells, and were first described by Mizoguchi and Bhan (82). The exact surface markers present in human Breg cells remain unclear. Different B cell subsets in circulation have suppressive regulatory functions that are dependent on IL-10, namely CD19+ CD24 $4^{\text {high }}$ CD $38^{\text {high }}$ Breg cells, CD19 ${ }^{+} \mathrm{CD} 24^{\text {high }} \mathrm{CD} 27^{+}$Breg cells, and CD25 $5^{\text {high }}$ CD27 $7^{\text {high }}$ CD $86^{\text {high }}$ CD $1^{\text {high }}$ Breg cells (8385). Recently, other Breg subsets, known as TGF- $\beta$ - expressing 
Breg cells, have also been identified (86). In autoimmune diseases, such as SLE, multiple sclerosis, lupus nephritis, and type 1 diabetes mellitus, Breg cells are found to be dysfunctional in terms of immune suppression, leading to the breakdown of selftolerance (87-92). In addition, adoptive transfer of Breg cells ameliorated inflammatory symptoms in animal models of many autoimmune diseases, including SLE, type I diabetes, and contact hypersensitivity (93-96).

\section{Breg Cells in Pemphigus Vulgaris}

Activated B cells are generally considered to be pathogenic regulators in patients with $\mathrm{PV}$ via the secretion of autoantibodies targeting Dsg3 (97). However, little attention has been paid to the function of Breg cells in the pathogenesis of PV. Several studies have shown that the frequency of $\mathrm{CD} 19^{+} \mathrm{CD} 24^{\text {high }} \mathrm{CD} 38^{\text {high }}$ Breg cells is significantly increased in the blood of patients with PV compared to that in healthy individuals, both in the active group and in remittent group $(98,99)$. Breg cells from patients with PV displayed impaired IL-10 expression, even when they were activated over a longer period of time, compared to the healthy Breg cells (98). Therefore, the Breg cells in PV did not directly regulate the humoral response, and rather lost their ability to down-regulate the production of IFN- $\gamma$ in $\mathrm{CD} 4^{+} \mathrm{T}$ cells (Figure 3). In addition, after being treated with rituximab or intravenous immunoglobulin (IVIG), patients with PV, showing complete remission, had a significantly higher proportion of IL10-secreting Breg cells and increased levels of IL-10 compared to those who showed no response and incomplete remission $(100,101)$. Maturation of IL-10-secreting progenitor B (B10 pro $)$ cells into functional IL-10-secreting effector B (B10 eff) cells has been confirmed to require IL-21- and CD40-dependent cognate interactions with T cells (102) (Figure 3). Whether patient-derived $\mathrm{B} 10$ cells in PV display a defective interaction with $\mathrm{T}$ cells, or fail to respond to IL-21 cytokines warrants further investigation.

\section{Breg Cells in Bullous Pemphigoid}

In 2007, Kabuto et al. had found no significant difference in the frequencies of $\mathrm{CD} 19^{+} \mathrm{CD} 24^{\text {high }} \mathrm{CD} 38^{\text {high }} \mathrm{B}$ cells between patients with BP and healthy controls (99). However, in our recent research, we found the frequency of circulating $\mathrm{CD} 19^{+}$ $\mathrm{CD} 24^{\text {high }} \mathrm{CD} 27^{+}$Breg cells and IL- $10^{+} \mathrm{CD} 19^{+}$Breg cells to be increased in patients with BP. In addition, these patient-derived Breg cells displayed impaired function regarding suppression of $\mathrm{CD}^{+} \mathrm{T}$ cell activation and autoantibody production, despite secreting high levels of tumor necrosis factor- $\alpha$ (TNF- $\alpha$ ) and IFN- $\gamma$ (Figure 3). Moreover, the TNF inhibitor etanercept could inhibit autoantibody production in vitro (103). According to our results, Breg cells in patients with BP displayed increased production of inflammatory cytokines (mainly TNF$\alpha$ ). Although there is an apparent inconsistency between the pro-inflammatory phenotype and weaker immunosuppressive function of Breg cells in patients with BP, recent studies have proposed immunosuppression not be controlled by a devoted Breg cell lineage with a specific phenotype; rather, it is rather the result of a dynamic balance between multiple $B$ cell subsets and other cells within the immune system (104). Therefore, functional flexibility of the Breg subset may be responsible for the difference in phenotypic vs. functional observations. Further analysis of the Breg phenotype will improve our understanding of its role in BP, and animal models should also be used to study the function of Breg cells in AIBD.

\section{OTHER REGULATORY CELLS}

In addition to the cells described above, there are several other cells that have been reported to possess immunomodulatory functions, including DCs, macrophages, MDSCs, and MSCs. Function of DCs is related to their maturation state: immature DCs promote tolerogenic response by expressing antiinflammatory molecules, such as IL-10 and TGF- $\beta$, whereas mature DCs promote immunogenic responses $(105,106)$. In addition, macrophages can be divided into three populations: classically activated macrophages, wound-healing macrophages, and regulatory macrophages (107). Regulatory macrophages produce high levels of IL-10 and low levels of IL-12, thereby dampening the immune response and limiting inflammation $(108,109)$. Moreover, MDSCs could also produce a large array of anti-inflammatory molecules, including arginase-1 (ARG1), TGF- $\beta$, IL-10, and indoleamine 2,3-dioxygenase (IDO), and have the ability of suppressing $\mathrm{T}$ cell response and promoting the functions of Treg cells (110-112). Furthermore, MSCs have been proven to have immunoregulatory effect on innate (NK cells) and adaptive immune system (DCs, B cells, and T cells) by cellular contact and/or secretion of regulatory molecules, such as TGF- $\beta 1$, HGF, IDO, Prostaglandin E2, and IL-10 (113-116). MSCs also possess the ability to promote the function of Treg cells, including $\mathrm{CD}^{+}{ }^{+} \mathrm{CD} 25^{\text {bright }} \mathrm{FoxP}^{+}$Treg cells and Tr1 cells (117).

Taken together, besides the Treg and Breg cells, many other kinds of cells also have regulatory functions on immune system, and are related to the pathology and/or treatment of autoimmune diseases. However, little is known about the role of these cells in AIBD. One case report had shown CTLA4overexpressing adipose tissue-derived MSCs transplantation could improve the clinical symptoms of a dog with pemphigus foliaceus (118), suggesting the therapeutic potential of these regulatory cells in AIBD. Further studies are recommended to investigate the roles of these regulatory cells in AIBD, as well as for its treatment.

\section{COMPLEMENT REGULATORY PROTEINS IN AIBD}

CRPs refer to an important class of regulatory proteins in the complement system that controls enzymatic cascades, assembly of the membrane attack complex, and homeostasis of the complement system $(119,120)$; they include CD55 (decay accelerating factor), CD59 (membrane inhibitor of reactive lysis; MIRL), CD35 (type 1 complement receptor; CR1), and CD46 (membrane cofactor protein; MCP). Since the over-activation of the complement system could injure the host, effectors of complement activation need to be tightly 


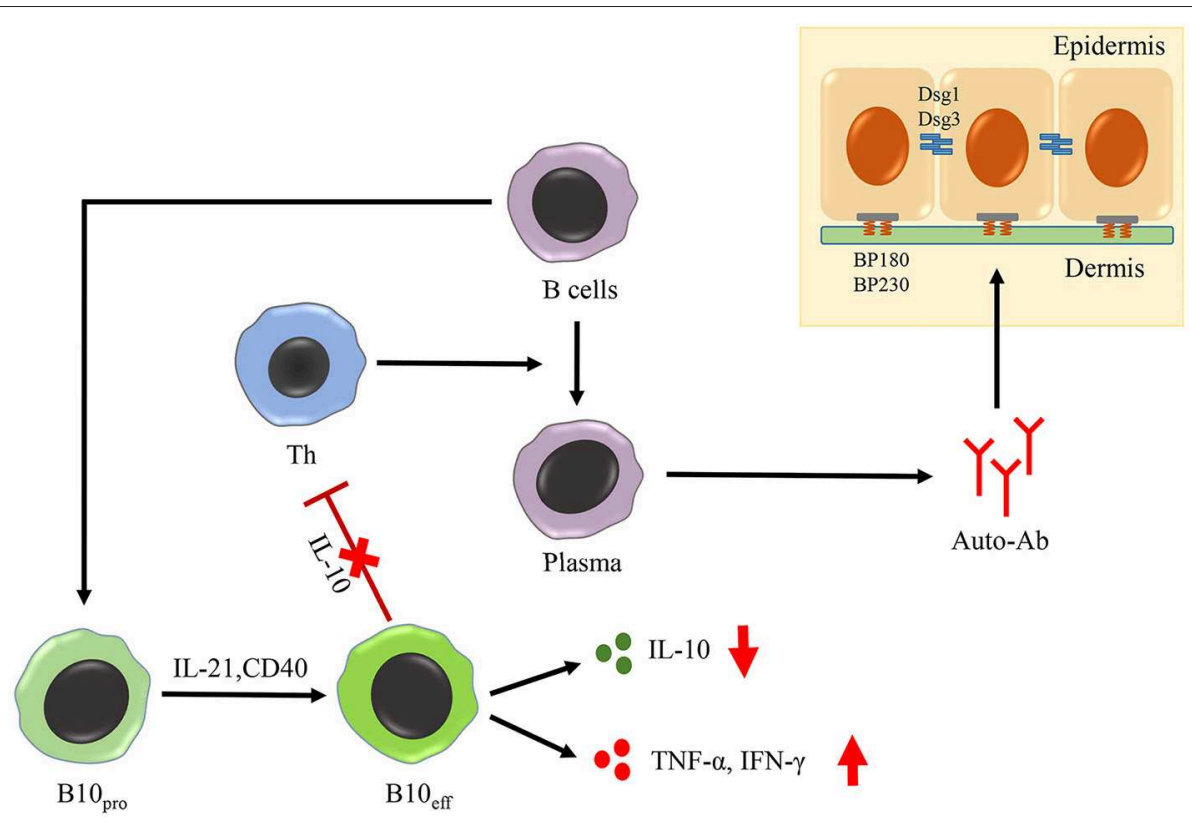

FIGURE 3 | Role of Breg cells in AIBD. The maturation of B10 pro cells into B10 eff cells requires IL-21- and CD40-dependent cognate interactions with T cells. In PV, $\mathrm{B} 10_{\text {eff }}$ cells is impaired in the functions of secreting IL-10 and down-regulating the production of IFN- $\gamma$ in CD4+ T cells. Moreover, Breg cells from BP patients acquire the function of producing TNF- $\alpha$ and IFN- $\gamma$, two important inflammatory cytokines in the pathogenesis of BP.

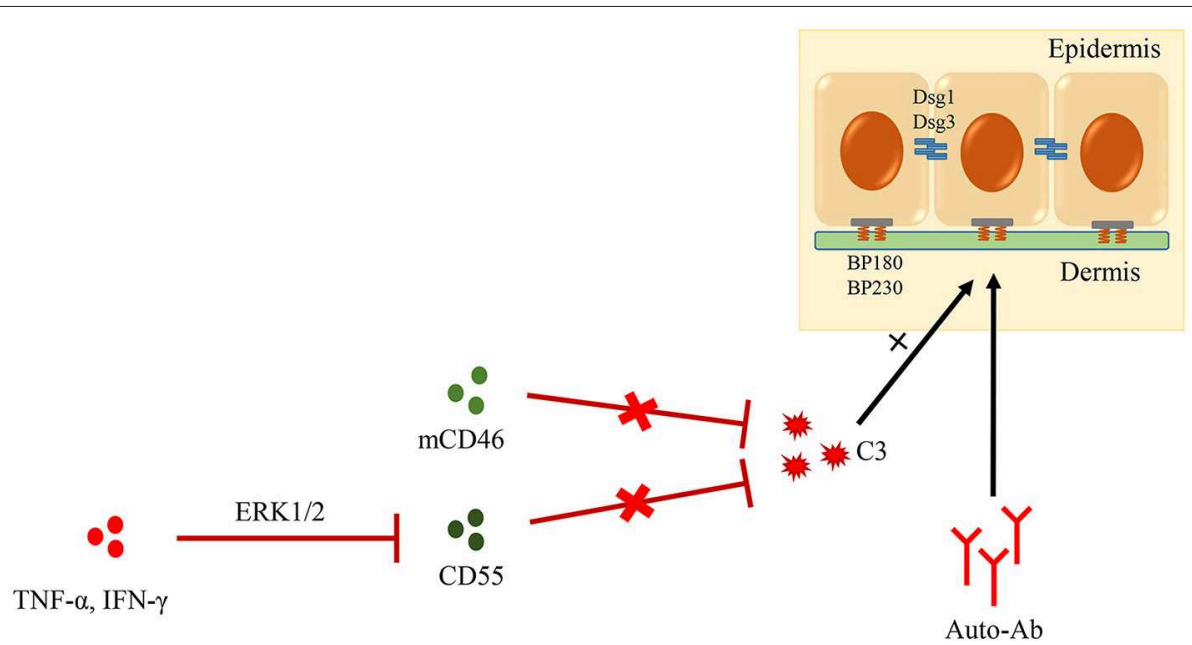

FIGURE 4 | Role of CRPs in AIBD. Complement activation is one of the pivotal steps in BP development. mCD46 and CD55, two important CRPs, could inhibit autoantibody-mediated complement activation. Additionally, CD55 is down-regulated by TNF- $\alpha$ and IFN- $\gamma$ though ERK1/2 signaling pathway in BP lesions.

regulated by complement regulatory proteins to maintain the balance between efficient destruction of harmful factors and unwanted over-activation of host tissue (121). Dysregulation of these proteins is related to many autoimmune diseases, including SLE, autoimmune hemocytopenias, and rheumatoid arthritis (122-126).

Although DIF studies of patients with PV often show C3 deposits at the keratinocyte surface, blister formation in $\mathrm{PV}$ has been proven to be independent of complement (127). Complement activation via the classical pathway is one of the pivotal steps in BP development (27). However, little is known about the role and mechanism of CRPs in BP. In our latest study, we examined the role of CD46 and CD55 in the pathogenesis of BP; results showed that sCD46 was up-regulated in both serum and blister fluid of the patients, and that its expression was positively correlated with the levels of anti-BP180 antibody and C3a. Importantly, the levels of mCD46 and CD55 were decreased in skin lesions of patients with BP. While the depletion of CD46 or CD55 enhanced C3 deposition and autoantibody-mediated complement activation, exogenous CD46 or CD55 significantly 
inhibited this phenomenon $(128,129)$ (Figure 4). These data suggested CD46 and CD55 to be key inhibitors of complement activation and that their down-regulation is involved in the pathogenesis of BP.

\section{CONCLUSION}

According to the previous results and our recent investigations, it is clear that the components of immunoregulatory system, including Treg cells, Breg cells, and CRPs, are important for the development of autoimmune disorders in AIBD. Recently, pharmacological approaches targeting Treg cells to restore their impaired function have been considered viable therapeutic methods for some autoimmune diseases (130-133), clarifying the importance of immunoregulatory system in the pathogenesis of these diseases, and showing the latent capacity of regulatory immune cells and molecules in these diseases. However, present studies have relied on the identification of changes in cell counts and functions, without exploring its role in disease development and treatment of AIBD in depth. Since the animal models of AIBD have been well-developed, more studies based on animal models would be required to expound the role and possible therapeutic applications of these cells and molecules in AIBD. Studies exploiting their suppressive characteristics should also be carefully designed to obtain maximum clinical benefits.

\section{REFERENCES}

1. Zhang Q, Vignali DA. Co-stimulatory and co-inhibitory pathways in autoimmunity. Immunity. (2016) 44:1034-51. doi: 10.1016/j.immuni.2016.04.017

2. Papp G, Boros P, Nakken B, Szodoray P, Zeher M. Regulatory immune cells and functions in autoimmunity and transplantation immunology. Autoimmun Rev. (2017) 16:435-44. doi: 10.1016/j.autrev.2017.03.011

3. Kleinewietfeld M, Hafler DA. Regulatory $\mathrm{T}$ cells in autoimmune neuroinflammation. Immunol Rev. (2014) 259:231-44. doi: 10.1111/imr.12169

4. Komatsu N, Takayanagi H. Regulatory T cells in Arthritis. Prog Mol Biol Transl Sci. (2015) 136:207-15. doi: 10.1016/bs.pmbts.2015.07.021

5. Tao JH, Cheng M, Tang JP, Liu Q, Pan F, Li XP. Foxp3, regulatory $\mathrm{T}$ cell, and autoimmune diseases. Inflammation. (2017) 40:328-39. doi: 10.1007/s10753-016-0470-8

6. Schmidt E, Zillikens D. Modern diagnosis of autoimmune blistering skin diseases. Autoimmun Rev. (2010) 10:84-9. doi: 10.1016/j.autrev.2010. 08.007

7. Baum S, Sakka N, Artsi O, Trau H, Barzilai A. Diagnosis and classification of autoimmune blistering diseases. Autoimmun Rev. (2014) 13:482-9. doi: 10.1016/j.autrev.2014.01.047

8. Schmidt E, Zillikens D. Pemphigoid diseases. Lancet. (2013) 381:320-32. doi: 10.1016/S0140-6736(12)61140-4

9. Kridin K. Pemphigus group: overview, epidemiology, mortality, and comorbidities. Immunol Res. (2018) 66:255-70. doi: 10.1007/s12026018-8986-7

10. Kasperkiewicz M, Ellebrecht CT, Takahashi H, Yamagami J, Zillikens D, Payne AS, et al. Pemphigus. Nat Rev Dis Primers. (2017) 3:17026. doi: $10.1038 /$ nrdp.2017.26

11. Bagci IS, Horvath ON, Ruzicka T, Sardy M. Bullous pemphigoid. Autoimmun Rev. (2017) 16:445-55. doi: 10.1016/j.autrev.2017.03.010

12. Yan L, Wang JM, Zeng K. Association between HLA-DRB1 polymorphisms and pemphigus vulgaris: a meta-analysis. Br J Dermatol. (2012) 167:768-77. doi: $10.1111 /$ j.1365-2133.2012.11040.x

\section{ETHICS STATEMENT}

All the patients gave written informed consent for the publication of the pictures.

\section{AUTHOR CONTRIBUTIONS}

TC and GW conceived the idea. TC, SS, HF, and BL contributed to the writing of the manuscript. TC contributed to figure preparation for the manuscript.

\section{FUNDING}

This work was supported by the National Natural Science Foundation of China (nos. 81703113, 81703116, and 81703125).

\section{ACKNOWLEDGMENTS}

We would like to thank Yu Ye, Juan Guo, Meihong Yu, and Wenjing Li for their help with histological analysis.

\section{SUPPLEMENTARY MATERIAL}

The Supplementary Material for this article can be found online at: https://www.frontiersin.org/articles/10.3389/fimmu. 2019.01746/full\#supplementary-material

13. Banfield CC, Wojnarowska F, Allen J, George S, Venning VA, Welsh KI. The association of HLA-DQ7 with bullous pemphigoid is restricted to men. $\mathrm{Br} \mathrm{J}$ Dermatol. (1998) 138:1085-90

14. Esmaili N, Mortazavi H, Chams-Davatchi C, Daneshpazhooh M, Damavandi MR, Aryanian Z, et al. Association between HLA-DQB1*03:01 and Bullous pemphigoid in Iranian patients. Iran J Immunol. (2013) 10:1-9.

15. Chagury AA, Sennes LU, Gil JM, Kalil J, Rodrigues H, Rosales CB, et al. HLA$\mathrm{C}^{*}$ 17, DQB1*03:01, DQA1*01:03 and DQA1*05:05 alleles associated to bullous pemphigoid in brazilian population. Ann Dermatol. (2018) 30:8-12. doi: 10.5021/ad.2018.30.1.8

16. Okazaki A, Miyagawa S, Yamashina Y, Kitamura W, Shirai T. Polymorphisms of HLA-DR and -DQ genes in Japanese patients with bullous pemphigoid. J Dermatol. (2000) 27:149-56. doi: 10.1111/j.1346-8138.2000. tb02141.x

17. Bystryn JC, Rudolph JL. Pemphigus. Lancet. (2005) 366:61-73. doi: 10.1016/S0140-6736(05)66829-8

18. Spindler V, Waschke J. Pemphigus-a disease of desmosome dysfunction caused by multiple mechanisms. Front Immunol. (2018) 9:136. doi: 10.3389/fimmu.2018.00136

19. Heupel WM, Zillikens D, Drenckhahn D, Waschke J. Pemphigus vulgaris IgG directly inhibit desmoglein 3-mediated transinteraction. J Immunol. (2008) 181:1825-34. doi: 10.4049/jimmunol.181.3.1825

20. Mao X, Sano Y, Park JM, Payne AS. p38 MAPK activation is downstream of the loss of intercellular adhesion in pemphigus vulgaris. J Biol Chem. (2011) 286:1283-91. doi: 10.1074/jbc.M110.172874

21. Williamson L, Hunziker T, Suter MM, Muller EJ. Nuclear c-Myc: a molecular marker for early stage pemphigus vulgaris. J Invest Dermatol. (2007) 127:1549-55. doi: 10.1038/sj.jid.5700735

22. Bektas M, Jolly PS, Berkowitz P, Amagai M, Rubenstein DS. A pathophysiologic role for epidermal growth factor receptor in pemphigus acantholysis. J Biol Chem. (2013) 288:9447-56. doi: 10.1074/jbc.M112.438010

23. Li N, Zhao M, Wang J, Liu Z, Diaz LA. Involvement of the apoptotic mechanism in pemphigus foliaceus autoimmune injury of the skin. $J$ Immunol. (2009) 182:711-7. doi: 10.4049/jimmunol.182.1.711 
24. Chen Y, Chernyavsky A, Webber RJ, Grando SA, Wang PH. Critical role of the neonatal $\mathrm{Fc}$ receptor $(\mathrm{FcRn})$ in the pathogenic action of antimitochondrial autoantibodies synergizing with anti-desmoglein autoantibodies in pemphigus vulgaris. J Biol Chem. (2015) 290:23826-37. doi: 10.1074/jbc.M115.668061

25. Liu Z, Sui W, Zhao M, Li Z, Li N, Thresher R, et al. Subepidermal blistering induced by human autoantibodies to BP180 requires innate immune players in a humanized bullous pemphigoid mouse model. J Autoimmun. (2008) 31:331-8. doi: 10.1016/j.jaut.2008.08.009

26. Chen R, Ning G, Zhao ML, Fleming MG, Diaz LA, Werb Z, et al. Mast cells play a key role in neutrophil recruitment in experimental bullous pemphigoid. J Clin Invest. (2001) 108:1151-8. doi: 10.1172/JCI11494

27. Nelson KC, Zhao M, Schroeder PR, Li N, Wetsel RA, Diaz LA, et al. Role of different pathways of the complement cascade in experimental bullous pemphigoid. J Clin Invest. (2006) 116:2892-900. doi: 10.1172/JCI17891

28. Zhao M, Trimbeger ME, Li N, Diaz LA, Shapiro SD, Liu Z. Role of FcRs in animal model of autoimmune bullous pemphigoid. J Immunol. (2006) 177:3398-405. doi: 10.4049/jimmunol.177.5.3398

29. Heimbach L, Li Z, Berkowitz P, Zhao M, Li N, Rubenstein DS, et al. The C5a receptor on mast cells is critical for the autoimmune skinblistering disease bullous pemphigoid. J Biol Chem. (2011) 286:15003-9. doi: $10.1074 /$ jbc.M111.221036

30. Lin L, Bankaitis E, Heimbach L, Li N, Abrink M, Pejler G, et al. Dual targets for mouse mast cell protease- 4 in mediating tissue damage in experimental bullous pemphigoid. J Biol Chem. (2011) 286:37358-67. doi: 10.1074/jbc.M111.272401

31. Liu Z, Zhou X, Shapiro SD, Shipley JM, Twining SS, Diaz LA, et al. The serpin alpha1-proteinase inhibitor is a critical substrate for gelatinase B/MMP-9 in vivo. Cell. (2000) 102:647-55. doi: 10.1016/s0092-8674(00)00087-8

32. Anhalt GJ, Labib RS, Voorhees JJ, Beals TF, Diaz LA. Induction of pemphigus in neonatal mice by passive transfer of IgG from patients with the disease. $N$ Engl J Med. (1982) 306:1189-96. doi: 10.1056/NEJM198205203062001

33. Amagai M, Tsunoda K, Suzuki H, Nishifuji K, Koyasu S, Nishikawa T. Use of autoantigen-knockout mice in developing an active autoimmune disease model for pemphigus. J Clin Invest. (2000) 105:625-31. doi: 10.1172/JCI8748

34. Takahashi H, Amagai M, Nishikawa T, Fujii Y, Kawakami Y, Kuwana M. Novel system evaluating in vivo pathogenicity of desmoglein 3-reactive $\mathrm{T}$ cell clones using murine pemphigus vulgaris. J Immunol. (2008) 181:1526-35. doi: 10.4049/jimmunol.181.2.1526

35. Takae Y, Nishikawa T, Amagai M. Pemphigus mouse model as a tool to evaluate various immunosuppressive therapies. Exp Dermatol. (2009) 18:252-60. doi: 10.1111/j.1600-0625.2008.00776.x

36. Liu Z, Diaz LA, Troy JL, Taylor AF, Emery DJ, Fairley JA, et al. A passive transfer model of the organ-specific autoimmune disease, bullous pemphigoid, using antibodies generated against the hemidesmosomal antigen, BP180. J Clin Invest. (1993) 92:2480-8. doi: 10.1172/JCI116856

37. Lessey E, Li N, Diaz L, Liu Z. Complement and cutaneous autoimmune blistering diseases. Immunol Res. (2008) 41:223-32. doi: 10.1007/s12026-008-8028-y

38. Hammers CM, Stanley JR. Mechanisms of disease: pemphigus and bullous pemphigoid. Annu Rev Pathol. (2016) 11:175-97. doi: 10.1146/annurev-pathol-012615-044313

39. Plitas G, Rudensky AY. Regulatory T cells: differentiation and function. Cancer Immunol Res. (2016) 4:721-5. doi: 10.1158/2326-6066.CIR-16-0193

40. Sakaguchi S, Sakaguchi N, Asano M, Itoh M, Toda M. Immunologic selftolerance maintained by activated $\mathrm{T}$ cells expressing IL-2 receptor alphachains (CD25). Breakdown of a single mechanism of self-tolerance causes various autoimmune diseases. J Immunol. (1995) 155:1151-64.

41. Sakaguchi S. Naturally arising Foxp3-expressing $\mathrm{CD} 25^{+} \mathrm{CD} 4^{+}$regulatory $\mathrm{T}$ cells in immunological tolerance to self and non-self. Nat Immunol. (2005) 6:345-52. doi: 10.1038/ni1178

42. Wing K, Onishi Y, Prieto-Martin P, Yamaguchi T, Miyara M, Fehervari Z, et al. CTLA- 4 control over Foxp $3^{+}$regulatory T cell function. Science. (2008) 322:271-5. doi: 10.1126/science.1160062

43. Levine AG, Arvey A, Jin W, Rudensky AY. Continuous requirement for the TCR in regulatory T cell function. Nat Immunol. (2014) 15:1070-8. doi: 10.1038/ni.3004
44. Chinen T, Kannan AK, Levine AG, Fan X, Klein U, Zheng Y, et al. An essential role for the IL-2 receptor in Treg cell function. Nat Immunol. (2016) 17:1322-33. doi: 10.1038/ni.3540

45. Galgani M, De Rosa V, La Cava A, Matarese G. Role of Metabolism in the Immunobiology of Regulatory T Cells. J Immunol. (2016) 197:2567-75. doi: 10.4049/jimmunol.1600242

46. Sugiyama H, Matsue H, Nagasaka A, Nakamura Y, Tsukamoto K, Shibagaki $\mathrm{N}$, et al. $\mathrm{CD} 4^{+} \mathrm{CD} 25^{\text {high }}$ regulatory $\mathrm{T}$ cells are markedly decreased in blood of patients with pemphigus vulgaris. Dermatology. (2007) 214:210-20. doi: $10.1159 / 000099585$

47. Asothai R, Anand V, Das D, Antil PS, Khandpur S, Sharma VK, et al. Distinctive Treg associated CCR4-CCL22 expression profile with altered frequency of Th17/Treg cell in the immunopathogenesis of Pemphigus Vulgaris. Immunobiology. (2015) 220:1129-35. doi: 10.1016/j.imbio.2015.06.008

48. Xu RC, Zhu HQ, Li WP, Zhao XQ, Yuan HJ, Zheng J, et al. The imbalance of Th17 and regulatory T cells in pemphigus patients. Eur J Dermatol. (2013) 23:795-802. doi: 10.1684/ejd.2013.2177

49. Yokoyama T, Matsuda S, Takae Y, Wada N, Nishikawa T, Amagai M, et al. Antigen-independent development of Foxp $3^{+}$regulatory T cells suppressing autoantibody production in experimental pemphigus vulgaris. Int Immunol. (2011) 23:365-73. doi: $10.1093 /$ intimm/dxr020

50. Schmidt T, Willenborg S, Hunig T, Deeg CA, Sonderstrup G, Hertl M, et al. Induction of $\mathrm{T}$ regulatory cells by the superagonistic anti-CD28 antibody D665 leads to decreased pathogenic IgG autoantibodies against desmoglein 3 in a HLA-transgenic mouse model of pemphigus vulgaris. Exp Dermatol. (2016) 25:293-8. doi: 10.1111/exd.12919

51. Bhattacharjee R, De D, Handa S, Minz RW, Saikia B, Joshi N. Assessment of the effects of rituximab monotherapy on different subsets of circulating T-regulatory cells and clinical disease severity in severe pemphigus vulgaris. Dermatology. (2016) 232:572-7. doi: 10.1159/000448031

52. Franks SE, Getahun A, Hogarth PM, Cambier JC. Targeting B cells in treatment of autoimmunity. Curr Opin Immunol. (2016) 43:39-45. doi: 10.1016/j.coi.2016.09.003

53. El-Zawahry B, Bassiouny D, Hegazy R, Gawdat H, Shalaby S, Khorshied M, et al. Rituximab treatment in pemphigus vulgaris: effect on circulating Tregs. Arch Dermatol Res. (2017) 309:551-6. doi: 10.1007/s00403-017-1754-z

54. Cao D, Malmstrom V, Baecher-Allan C, Hafler D, Klareskog L, Trollmo C. Isolation and functional characterization of regulatory $\mathrm{CD} 25^{\text {bright }} \mathrm{CD} 4^{+}$ $\mathrm{T}$ cells from the target organ of patients with rheumatoid arthritis. Eur $J$ Immunol. (2003) 33:215-23. doi: 10.1002/immu.200390024

55. Vigna-Perez M, Hernandez-Castro B, Paredes-Saharopulos O, PortalesPerez D, Baranda L, Abud-Mendoza C, et al. Clinical and immunological effects of Rituximab in patients with lupus nephritis refractory to conventional therapy: a pilot study. Arthritis Res Ther. (2006) 8:R83. doi: $10.1186 / \operatorname{ar} 1954$

56. Stasi R, Cooper N, Del Poeta G, Stipa E, Laura Evangelista M, Abruzzese E, et al. Analysis of regulatory T-cell changes in patients with idiopathic thrombocytopenic purpura receiving B cell-depleting therapy with rituximab. Blood. (2008) 112:1147-50. doi: 10.1182/blood-2007-12-1 29262

57. Catzola V, Battaglia A, Buzzonetti A, Fossati M, Scuderi F, Fattorossi $\mathrm{A}$, et al. Changes in regulatory $\mathrm{T}$ cells after rituximab in two patients with refractory myasthenia gravis. J Neurol. (2013) 260:2163-5. doi: $10.1007 /$ s00415-013-6987-y

58. Quaglino P, Antiga E, Comessatti A, Caproni M, Nardo T, Ponti R, et al. Circulating $\mathrm{CD}^{+} \mathrm{CD}^{+} 5$ brightFOXP3 ${ }^{+}$regulatory T-cells are significantly reduced in bullous pemphigoid patients. Arch Dermatol Res. (2012) 304:63945. doi: 10.1007/s00403-012-1213-9

59. Antiga E, Quaglino P, Volpi W, Pierini I, Del Bianco E, Bianchi B, et al. Regulatory $\mathrm{T}$ cells in skin lesions and blood of patients with bullous pemphigoid. J Eur Acad Dermatol Venereol. (2014) 28:222-30. doi: $10.1111 /$ jdv.12091

60. Muramatsu K, Ujiie H, Kobayashi I, Nishie W, Izumi K, Ito T, et al. Regulatory T-cell dysfunction induces autoantibodies to bullous pemphigoid antigens in mice and human subjects. J Allergy Clin Immunol. (2018) 142:1818-1830.e6. doi: 10.1016/j.jaci.2018.03.014 
61. Haeberle S, Wei X, Bieber K, Goletz S, Ludwig RJ, Schmidt E, et al. Regulatory T-cell deficiency leads to pathogenic bullous pemphigoid antigen 230 autoantibody and autoimmune bullous disease. J Allergy Clin Immunol. (2018) 142:1831-1842.e7. doi: 10.1016/j.jaci.2018.04.006

62. Rensing-Ehl A, Gaus B, Bruckner-Tuderman L, Martin SF. Frequency, function and CLA expression of $\mathrm{CD}^{+} \mathrm{CD} 25^{+} \mathrm{FOXP}^{+}$regulatory $\mathrm{T}$ cells in bullous pemphigoid. Exp Dermatol. (2007) 16:13-21. doi: 10.1111/j.1600-0625.2006.00522.x

63. Curotto de Lafaille MA, Lafaille JJ. Natural and adaptive foxp $3^{+}$regulatory T cells: more of the same or a division of labor? Immunity. (2009) 30:626-35. doi: 10.1016/j.immuni.2009.05.002

64. Roncarolo MG, Gregori S, Battaglia M, Bacchetta R, Fleischhauer $\mathrm{K}$, Levings MK. Interleukin-10-secreting type 1 regulatory $\mathrm{T}$ cells in rodents and humans. Immunol Rev. (2006) 212:28-50. doi: 10.1111/j.0105-2896.2006.00420.x

65. Weiner HL. Induction and mechanism of action of transforming growth factor-beta-secreting Th3 regulatory cells. Immunol Rev. (2001) 182:207-14. doi: 10.1034/j.1600-065X.2001.1820117.x

66. Chien $\mathrm{CH}$, Chiang BL. Regulatory $\mathrm{T}$ cells induced by B cells: a novel subpopulation of regulatory T cells. J Biomed Sci. (2017) 24:86. doi: 10.1186/s12929-017-0391-3

67. Groux H, O'Garra A, Bigler M, Rouleau M, Antonenko S, de Vries JE, et al. A CD4 ${ }^{+}$T-cell subset inhibits antigen-specific T-cell responses and prevents colitis. Nature. (1997) 389:737-42. doi: 10.1038/39614

68. Veldman C, Hohne A, Dieckmann D, Schuler G, Hertl M. Type I regulatory $\mathrm{T}$ cells specific for desmoglein 3 are more frequently detected in healthy individuals than in patients with pemphigus vulgaris. J Immunol. (2004) 172:6468-75. doi: 10.4049/jimmunol.172.10.6468

69. Veldman C, Pahl A, Hertl M. Desmoglein 3-specific T regulatory 1 cells consist of two subpopulations with differential expression of the transcription factor Foxp3. Immunology. (2009) 127:40-9. doi: 10.1111/j.1365-2567.2008.02932.x

70. Veldman C, Pahl A, Beissert S, Hansen W, Buer J, Dieckmann D, et al. Inhibition of the transcription factor Foxp3 converts desmoglein 3-specific type 1 regulatory T cells into Th2-like cells. J Immunol. (2006) 176:3215-22. doi: 10.4049/jimmunol.176.5.3215

71. Billerbeck E, Thimme R. $\mathrm{CD}^{+}$regulatory $\mathrm{T}$ cells in persistent human viral infections. Hum Immunol. (2008) 69:771-5. doi: 10.1016/j.humimm.2008.07.016

72. Sakaguchi S, Yamaguchi T, Nomura T, Ono M. Regulatory T cells and immune tolerance. Cell. (2008) 133:775-87. doi: 10.1016/j.cell.2008.05.009

73. Suzuki M, Konya C, Goronzy JJ, Weyand CM. Inhibitory CD8 ${ }^{+}$ $\mathrm{T}$ cells in autoimmune disease. Hum Immunol. (2008) 69:781-9. doi: 10.1016/j.humimm.2008.08.283

74. Cosmi L, Liotta F, Lazzeri E, Francalanci M, Angeli R, Mazzinghi B, et al. Human $\mathrm{CD} 8^{+} \mathrm{CD} 25^{+}$thymocytes share phenotypic and functional features with $\mathrm{CD} 4{ }^{+} \mathrm{CD} 25^{+}$regulatory thymocytes. Blood. (2003) 102:410714. doi: 10.1182/blood-2003-04-1320

75. Jarvis LB, Matyszak MK, Duggleby RC, Goodall JC, Hall FC, Gaston JS. Autoreactive human peripheral blood $\mathrm{CD}^{+} \mathrm{T}$ cells with a regulatory phenotype and function. Eur J Immunol. (2005) 35:2896-908. doi: 10.1002/eji.200526162

76. Rifa'I M, Kawamoto Y, Nakashima I, Suzuki H. Essential roles of $\mathrm{CD}^{+}{ }^{+} \mathrm{CD} 122^{+}$regulatory $\mathrm{T}$ cells in the maintenance of $\mathrm{T}$ cell homeostasis. $J$ Exp Med. (2004) 200:1123-34. doi: 10.1084/jem.20040395

77. Endharti AT, Rifa IM, Shi Z, Fukuoka Y, Nakahara Y, Kawamoto Y, et al. Cutting edge: $\mathrm{CD}^{+}{ }^{\mathrm{CD}} 122^{+}$regulatory $\mathrm{T}$ cells produce IL-10 to suppress IFN-gamma production and proliferation of $\mathrm{CD}^{+} \mathrm{T}$ cells. J Immunol. (2005) 175:7093-7. doi: 10.4049/jimmunol.175.11.7093

78. Shi Z, Okuno Y, Rifa'I M, Endharti AT, Akane K, Isobe K, et al. Human $\mathrm{CD}^{+}{ }^{+} \mathrm{CXCR}^{+}{ }^{+} \mathrm{T}$ cells have the same function as murine $\mathrm{CD} 8{ }^{+} \mathrm{CD} 122^{+}$ Treg. Eur J Immunol. (2009) 39:2106-19. doi: 10.1002/eji.200939314

79. Lerret NM, Houlihan JL, Kheradmand T, Pothoven KL, Zhang ZJ, Luo X. Donor-specific $\mathrm{CD}^{+}$Foxp3 $^{+} \mathrm{T}$ cells protect skin allografts and facilitate induction of conventional $\mathrm{CD}^{+}{ }^{+}$Foxp $^{+}$regulatory $\mathrm{T}$ cells. Am J Transplant. (2012) 12:2335-47. doi: 10.1111/j.1600-6143.2012. 04120.x
80. Filaci G, Bacilieri S, Fravega M, Monetti M, Contini P, Ghio M, et al. Impairment of $\mathrm{CD}^{+} \mathrm{T}$ suppressor cell function in patients with active systemic lupus erythematosus. J Immunol. (2001) 166:6452-7. doi: 10.4049/jimmunol.166.10.6452

81. Lee YH, Ishida Y, Rifa'I M, Shi Z, Isobe K, Suzuki H. Essential role of $\mathrm{CD}^{+} \mathrm{CD} 122^{+}$regulatory $\mathrm{T}$ cells in the recovery from experimental autoimmune encephalomyelitis. J Immunol. (2008) 180:825-832. doi: 10.4049/jimmunol.180.2.825

82. Mizoguchi A, Bhan AK. A case for regulatory B cells. J Immunol. (2006) 176:705-10. doi: 10.4049/jimmunol.176.2.705

83. Blair PA, Norena LY, Flores-Borja F, Rawlings DJ, Isenberg DA, Ehrenstein MR, et al. CD19( $\left.{ }^{+}\right) \mathrm{CD} 24(\mathrm{hi}) \mathrm{CD} 38(\mathrm{hi}) \mathrm{B}$ cells exhibit regulatory capacity in healthy individuals but are functionally impaired in systemic Lupus Erythematosus patients. Immunity. (2010) 32:129-40. doi: 10.1016/j.immuni.2009.11.009

84. Kessel A, Haj T, Peri R, Snir A, Melamed D, Sabo E, et al. Human $\mathrm{CD} 19\left(^{+}\right) \mathrm{CD} 25$ (high) B regulatory cells suppress proliferation of $\mathrm{CD} 4\left(^{+}\right)$ $\mathrm{T}$ cells and enhance Foxp3 and CTLA-4 expression in T-regulatory cells. Autoimmun Rev. (2012) 11:670-7. doi: 10.1016/j.autrev.2011.11.018

85. Zha B, Wang L, Liu X, Liu J, Chen Z, Xu J, et al. Decrease in proportion of $\mathrm{CD} 19^{+} \mathrm{CD} 24$ (hi) $\mathrm{CD}^{+} 7^{+} \mathrm{B}$ cells and impairment of their suppressive function in Graves' disease. PLoS ONE. (2012) 7:e49835. doi: 10.1371/journal.pone.0049835

86. Lee JH, Noh J, Noh G, Choi WS, Cho S, Lee SS. Allergen-specific transforming growth factor-beta-producing $\mathrm{CD} 19^{+} \mathrm{CD} 5^{+}$regulatory B-cell $(\mathrm{Br} 3)$ responses in human late eczematous allergic reactions to cow's milk. $J$ Interferon Cytokine Res. (2011) 31:441-9. doi: 10.1089/jir.2010.0020

87. Giannoukakis N, Trucco M. A role for tolerogenic dendritic cell-induced Bregulatory cells in type 1 diabetes mellitus. Curr Opin Endocrinol Diabetes Obes. (2012) 19:279-87. doi: 10.1097/MED.0b013e328355461b

88. Michel L, Chesneau M, Manceau P, Genty A, Garcia A, Salou M, et al. Unaltered regulatory B-cell frequency and function in patients with multiple sclerosis. Clin Immunol. (2014) 155:198-208. doi: 10.1016/j.clim.2014.09.011

89. Vadasz Z, Peri R, Eiza N, Slobodin G, Balbir-Gurman A, Toubi E. The Expansion of CD25 high IL-10 high FoxP3 high B regulatory cells is in association with SLE disease activity. J Immunol Res. (2015) 2015:254245. doi: $10.1155 / 2015 / 254245$

90. Han J, Sun L, Fan X, Wang Z, Cheng Y, Zhu J, et al. Role of regulatory b cells in neuroimmunologic disorders. J Neurosci Res. (2016) 94:693-701. doi: 10.1002/jnr.23749

91. Heinemann K, Wilde B, Hoerning A, Tebbe B, Kribben A, Witzke O, et al. Decreased $\mathrm{IL}_{-10}\left(^{+}\right)$regulatory B cells (Bregs) in lupus nephritis patients. Scand J Rheumatol. (2016) 45:312-6. doi: 10.3109/03009742.2015.11 26346

92. Menon M, Blair PA, Isenberg DA, Mauri C. A regulatory feedback between plasmacytoid dendritic cells and regulatory B cells is aberrant in systemic lupus erythematosus. Immunity. (2016) 44:683-97. doi: 10.1016/j.immuni.2016.02.012

93. Matsushita T, Yanaba K, Bouaziz JD, Fujimoto M, Tedder TF. Regulatory $\mathrm{B}$ cells inhibit EAE initiation in mice while other B cells promote disease progression. J Clin Invest. (2008) 118:3420-30. doi: 10.1172/JCI36030

94. Matsushita T. Regulatory B cells in mouse models of systemic lupus erythematosus (SLE). Methods Mol Biol. (2014) 1190:195-205. doi: 10.1007/978-1-4939-1161-5_14

95. Ray A, Basu S. Regulatory B cells in experimental autoimmune encephalomyelitis (EAE). Methods Mol Biol. (2014) 1190:243-55. doi: 10.1007/978-1-4939-1161-5_17

96. Rosser EC, Mauri C. Regulatory B cells in experimental mouse models of arthritis. Methods Mol Biol. (2014) 1190:183-94. doi: 10.1007/978-1-4939-1161-5_13

97. DiMarco C. Pemphigus: pathogenesis to treatment. R I Med J. (2016) 99:28-31.

98. Zhu HQ, Xu RC, Chen YY, Yuan HJ, Cao H, Zhao XQ, et al. Impaired function of $\mathrm{CD}_{19}\left(^{+}\right) \mathrm{CD} 24(\mathrm{hi}) \mathrm{CD} 38$ (hi) regulatory B cells in patients with pemphigus. Br J Dermatol. (2015) 172:101-10. doi: 10.1111/bjd.13192

99. Kabuto M, Fujimoto N, Takahashi T, Tanaka T. Decreased level of interleukin-10-producing $\mathrm{B}$ cells in patients with pemphigus but not 
in patients with pemphigoid. Br J Dermatol. (2017) 176:1204-12. doi: 10.1111/bjd.15113

100. Colliou N, Picard D, Caillot F, Calbo S, Le Corre S, Lim A, et al. Longterm remissions of severe pemphigus after rituximab therapy are associated with prolonged failure of desmoglein B cell response. Sci Transl Med. (2013) 5:175ra130. doi: 10.1126/scitranslmed.3005166

101. Kabuto M, Fujimoto $\mathrm{N}$, Tanaka $\mathrm{T}$. Increase of interleukin-10producing $B$ cells associated with long-term remission after i.v. immunoglobulin treatment for pemphigus. J Dermatol. (2016) 43:815-8. doi: $10.1111 / 1346-8138.13295$

102. Yoshizaki A, Miyagaki T, DiLillo DJ, Matsushita T, Horikawa M, Kountikov EI, et al. Regulatory B cells control T-cell autoimmunity through IL-21-dependent cognate interactions. Nature. (2012) 491:264-8. doi: 10.1038/nature11501

103. Liu Z, Dang E, Li B, Qiao H, Jin L, Zhang J, et al. Dysfunction of $\mathrm{CD} 19\left(^{+}\right) \mathrm{CD} 24(\mathrm{hi}) \mathrm{CD} 27\left(^{+}\right) \mathrm{B}$ regulatory cells in patients with bullous pemphigoid. Sci Rep. (2018) 8:703. doi: 10.1038/s41598-018-19226-z

104. Rosser EC, Mauri C. Regulatory B cells: origin, phenotype, and function. Immunity. (2015) 42:607-12. doi: 10.1016/j.immuni.2015.04.005

105. Manicassamy S, Pulendran B. Dendritic cell control of tolerogenic responses. Immunol Rev. (2011) 241:206-27. doi: 10.1111/j.1600-065X.2011.01015.x

106. Liu J, Cao X. Regulatory dendritic cells in autoimmunity: a comprehensive review. J Autoimmun. (2015) 63:1-12. doi: 10.1016/j.jaut.2015.07.011

107. Mosser DM, Edwards JP. Exploring the full spectrum of macrophage activation. Nat Rev Immunol. (2008) 8:958-69. doi: 10.1038/nri2448

108. Gerber JS, Mosser DM. Reversing lipopolysaccharide toxicity by ligating the macrophage Fc gamma receptors. J Immunol. (2001) 166:6861-8. doi: 10.4049/jimmunol.166.11.6861

109. Fleming BD, Mosser DM. Regulatory macrophages: setting the threshold for therapy. Eur J Immunol. (2011) 41:2498-502. doi: 10.1002/eji.201141717

110. Gabrilovich DI, Ostrand-Rosenberg S, Bronte V. Coordinated regulation of myeloid cells by tumours. Nat Rev Immunol. (2012) 12:253-68. doi: $10.1038 /$ nri3175

111. Luan Y, Mosheir E, Menon MC, Wilson D, Woytovich C, Ochando J, et al. Monocytic myeloid-derived suppressor cells accumulate in renal transplant patients and mediate CD $4\left(^{+}\right)$Foxp $3\left(^{+}\right)$Treg expansion. Am J Transplant. (2013) 13:3123-31. doi: 10.1111/ajt.12461

112. Gabrilovich DI. Myeloid-derived suppressor cells. Cancer Immunol Res. (2017) 5:3-8. doi: 10.1158/2326-6066.CIR-16-0297

113. Aggarwal S, Pittenger MF. Human mesenchymal stem cells modulate allogeneic immune cell responses. Blood. (2005) 105:1815-22. doi: 10.1182/blood-2004-04-1559

114. Jiang XX, Zhang Y, Liu B, Zhang SX, Wu Y, Yu XD, et al. Human mesenchymal stem cells inhibit differentiation and function of monocyte-derived dendritic cells. Blood. (2005) 105:4120-6. doi: 10.1182/blood-2004-02-0586

115. Castro-Manrreza ME, Montesinos JJ. Immunoregulation by mesenchymal stem cells: biological aspects and clinical applications. J Immunol Res. (2015) 2015:394917. doi: 10.1155/2015/394917

116. Najar M, Raicevic G, Fayyad-Kazan H, De Bruyn C, Bron D, Toungouz $\mathrm{M}$, et al. Bone marrow mesenchymal stromal cells induce proliferative, cytokinic and molecular changes during the $\mathrm{T}$ cell response: the importance of the IL-10/CD210 Axis. Stem Cell Rev. (2015) 11:442-52. doi: $10.1007 /$ s12015-014-9567-3

117. Yan Z, Zhuansun Y, Chen R, Li J, Ran P. Immunomodulation of mesenchymal stromal cells on regulatory $\mathrm{T}$ cells and its possible mechanism. Exp Cell Res. (2014) 324:65-74. doi: 10.1016/j.yexcr.2014.03.013

118. Han SM, Kim HT, Kim KW, Jeon KO, Seo KW, Choi EW, et al. CTLA4 overexpressing adipose tissue-derived mesenchymal stem cell therapy in a dog with steroid-refractory pemphigus foliaceus. BMC Vet Res. (2015) 11:49. doi: 10.1186/s12917-015-0371-3

119. Miwa T, Song WC. Membrane complement regulatory proteins: insight from animal studies and relevance to human diseases. Int Immunopharmacol. (2001) 1:445-59. doi: 10.1016/S1567-5769(00)00043-6
120. Noris M, Remuzzi G. Overview of complement activation and regulation. Semin Nephrol. (2013) 33:479-92. doi: 10.1016/j.semnephrol.2013. 08.001

121. Merle NS, Church SE, Fremeaux-Bacchi V, Roumenina LT. Complement system part I - molecular mechanisms of activation and regulation. Front Immunol. (2015) 6:262. doi: 10.3389/fimmu.2015.00262

122. Garcia-Valladares I, Atisha-Fregoso Y, Richaud-Patin Y, JakezOcampo J, Soto-Vega E, Elias-Lopez D, et al. Diminished expression of complement regulatory proteins (CD55 and CD59) in lymphocytes from systemic lupus erythematosus patients with lymphopenia. Lupus. (2006) 15:600-5. doi: 10.1177/09612033060 71916

123. Ruiz-Arguelles A, Llorente L. The role of complement regulatory proteins (CD55 and CD59) in the pathogenesis of autoimmune hemocytopenias. Autoimmun Rev. (2007) 6:155-61. doi: 10.1016/j.autrev.2006. 09.008

124. Alegretti AP, Mucenic T, Merzoni J, Faulhaber GA, Silla LM, Xavier RM. Expression of CD55 and CD59 on peripheral blood cells from systemic lupus erythematosus (SLE) patients. Cell Immunol. (2010) 265:127-32. doi: 10.1016/j.cellimm.2010.07.013

125. Piccoli AK, Alegretti AP, Schneider L, Lora PS, Xavier RM. Expression of complement regulatory proteins CD55, CD59, CD35, and CD46 in rheumatoid arthritis. Rev Bras Reumatol. (2011) 51:503-10. doi: 10.1590/S0482-50042011000500009

126. Das N. Complement and membrane-bound complement regulatory proteins as biomarkers and therapeutic targets for autoimmune inflammatory disorders, RA and SLE. Indian J Exp Biol. (2015) 53:701-13.

127. Dainichi T, Chow Z, Kabashima K. IgG4, complement, and the mechanisms of blister formation in pemphigus and bullous pemphigoid. J Dermatol Sci. (2017) 88:265-70. doi: 10.1016/j.jdermsci.2017.07.012

128. Qiao P, Dang E, Cao T, Fang H, Zhang J, Qiao H, et al. Dysregulation of mCD46 and sCD46 contribute to the pathogenesis of bullous pemphigoid. Sci Rep. (2017) 7:145. doi: 10.1038/s41598-017-00235-3

129. Qiao P, Dang EL, Fang H, Zhang JY, Li B, Shen SX, et al. Decreased expression levels of complement regulator CD55 contribute to the development of bullous pemphigoid. Oncotarget. (2018) 9:35517-27. doi: 10.18632 /oncotarget.21216

130. Ochi H, Abraham M, Ishikawa H, Frenkel D, Yang K, Basso AS, et al. Oral CD3-specific antibody suppresses autoimmune encephalomyelitis by inducing $\mathrm{CD}^{+}{ }^{+} \mathrm{CD} 25-\mathrm{LAP}^{+} \mathrm{T}$ cells. Nat Med. (2006) 12:627-35. doi: $10.1038 / \mathrm{nm} 1408$

131. Ishikawa H, Ochi H, Chen ML, Frenkel D, Maron R, Weiner HL. Inhibition of autoimmune diabetes by oral administration of anti-CD3 monoclonal antibody. Diabetes. (2007) 56:2103-9. doi: 10.2337/db06-1632

132. Yamashita T, Sasaki N, Kasahara K, Hirata K. Anti-inflammatory and immune-modulatory therapies for preventing atherosclerotic cardiovascular disease. J Cardiol. (2015) 66:1-8. doi: 10.1016/j.jjcc.2015. 02.002

133. Fasching P, Stradner M, Graninger W, Dejaco C, Fessler J. Therapeutic potential of targeting the Th17/Treg axis in autoimmune disorders. Molecules. (2017) 22:134. doi: 10.3390/molecules220 10134

Conflict of Interest Statement: The authors declare that the research was conducted in the absence of any commercial or financial relationships that could be construed as a potential conflict of interest.

Copyright $\odot 2019$ Cao, Shao, Fang, Li and Wang. This is an open-access article distributed under the terms of the Creative Commons Attribution License (CC BY). The use, distribution or reproduction in other forums is permitted, provided the original author(s) and the copyright owner(s) are credited and that the original publication in this journal is cited, in accordance with accepted academic practice. No use, distribution or reproduction is permitted which does not comply with these terms. 